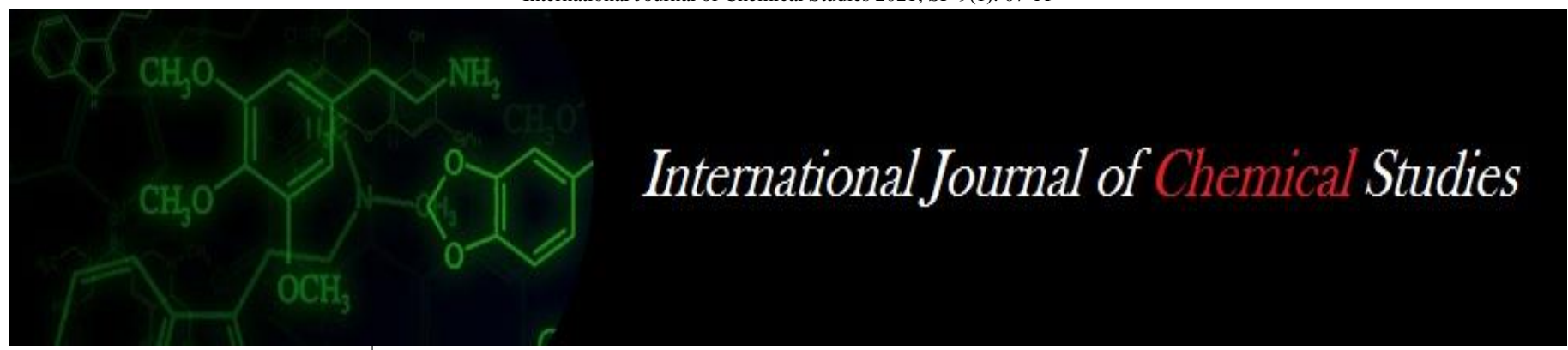

P-ISSN: 2349-8528

E-ISSN: 2321-4902

www.chemijournal.com

IJCS 2021; SP-9(1): 07-11

(C) 2021 IJCS

Received: 06-11-2020

Accepted: 09-12-2020

Ashirbachan Mahapatra

(1) Indira Gandhi Krishi

Vishwavidyalaya, Raipur,

Chhattisgarh, India

(2) ICAR - National Rice Research

Institute, Cuttack, Odisha, India

Sanjoy Saha

ICAR - National Rice Research

Institute, Cuttack, Odisha, India

Sushmita Munda

ICAR - National Rice Research

Institute, Cuttack, Odisha, India

\section{Sunita Meher}

Indira Gandhi Krishi

Vishwavidyalaya, Raipur,

Chhattisgarh, India.

\section{Hemant Kumar Jangde}

Indira Gandhi Krishi

Vishwavidyalaya, Raipur,

Chhattisgarh, India

Jagadish Jena

(1) Indira Gandhi Krishi

Vishwavidyalaya, Raipur,

Chhattisgarh, India

(2) ICAR - National Rice Research

Institute, Cuttack, Odisha, India

Ramakrushna Bastia

(1) ICAR - National Rice Research Institute, Cuttack, Odisha, India

(2) Odisha University of

Agriculture and Technology,

Bhubaneswar, Odisha, India

Hari Narayan

(1) Indira Gandhi Krishi

Vishwavidyalaya, Raipur,

Chhattisgarh, India

(2) ICAR - National Rice Research

Institute, Cuttack, Odisha, India

Corresponding Author:

Sanjoy Saha

ICAR - National Rice Research

Institute, Cuttack, Odisha, India

\section{Herbicide mixture mediated soil environment analysis in wet direct-sown rice}

\author{
Ashirbachan Mahapatra, Sanjoy Saha, Sushmita Munda, Sunita Meher, \\ Hemant Kumar Jangde, Jagadish Jena, Ramakrushna Bastia and Hari \\ Narayan
}

DOI: https://doi.org/10.22271/chemi.2021.v9.i1a.11219

\begin{abstract}
Direct-sown rice is the possible alternative to the conventional puddled transplanted rice as it saves resources viz. water, labour and time. Pre-germinated (sprouted) seeds are sown on puddled soil in wet direct-sown rice. But weed infestation is the major yield compromising factor under this environment as the weeds emerge simultaneously with the rice and compete from the beginning. Among the weed control methods, herbicide-based weed control is the most effective and efficient method. However single herbicide application in a long run leads to weed flora shift and development of herbicide resistance in weeds. In contrast, herbicide mixtures with different mode of action are the possible alternative to reduce the herbicide resistance and to broaden the weed control spectrum season long. But soil environment aspect is important for sustainable rice farming using herbicide mixtures. This investigation was done in Research farm of ICAR - National Rice Research Institute, Cuttack, Odisha in wet season of 2016. The experiment was laid out in randomized complete block design with nine treatments viz. herbicide mixture florpyrauxifen-benzyl + cyhalofop-butyl in four doses i.e. $120,150,180$ and $360 \mathrm{~g} / \mathrm{ha}$; florpyrauxifen-benzyl in two doses i.e. 25 and $30 \mathrm{~g} / \mathrm{ha}$; bispyribac-sodium at $30 \mathrm{~g} / \mathrm{ha}$; weed free and weedy check; replicated thrice. Soil environment parameters viz. microbial-biomass carbon, FDA hydrolase activity, dehydrogenase activity and urease activity were studied before, 4, 10, 20 and 30 days after herbicide treatments. The herbicide mixture florpyrauxifen-benzyl + cyhalofop-butyl at 150 $\mathrm{g} / \mathrm{ha}(4.91 \mathrm{t} / \mathrm{ha})$ was found to be the most effective herbicide showing no detrimental effect on soil environment of wet direct-sown rice after 10 days of application and yielding at par with the weed free (5.27 t/ha).
\end{abstract}

Keywords: Herbicide mixture, microbial biomass carbon, soil enzymes, wet direct-sown rice

\section{Introduction}

There are two major global issues; one is food security and another one is environmental sustainability. Rice (Oryza sativa L.) is an obvious target for attaining food security as it is staple food for more than half of the world population. The conventional method of rice crop husbandry is transplanting which is a water and labour intensive method ${ }^{[11]}$. On the contrary, direct-sown rice (DSR) is advantageous over it being water and labour saving and having 8-10 days of earlier maturity of the crop; hence costs less ${ }^{[3,21]}$. Therefore, DSR could be a possible alternative to save this huge amount of resources. But, DSR is very prone to weed infestation which compromises the yield even up to $100 \%{ }^{[20]}$. Among different weed control methods, chemical weed control has been proved to be the smartest, economic, most effective and efficient method under growing labour scarcity scenario ${ }^{[5]}$. But use of single herbicide with same mode of action in long run may lead to weed flora shift and development of herbicide resistance in weeds. Similarly use of single herbicide seldom proves to be satisfactory in season $\log$ weed control due to its narrow spectrum ${ }^{[18]}$. So use of herbicide mixture with different mode of action is the possible alternative which broadens the weed control spectrum delaying in the appearance of the resistant weed species ${ }^{[7]}$.

However, herbicide mixtures persist in soil which may have some non-target effects such as the effect on soil microorganisms ${ }^{[9]}$. Soil microbial activities are important soil fertility indicators and soil microorganism mediated biochemical transformations of organic matter that support essential ecosystem functions viz. decomposition and mineralization of nutrients. 
Herbicide mixtures may affect the soil microbial communities which are responsible for different soil enzyme dynamics ${ }^{[6,2]}$ which necessitates the need to assess the risk of application of herbicide mixtures on soil microbial properties. On this background, an attempt was made to assess the soil environmental impacts of the new herbicide mixture i.e. florpyrauxifen-benzyl + cyhalofop-butyl. Cyhalofop-butyl, one of the popular post emergence herbicides in rice from aryloxyphenoxy propionate group having acetyl CoA carboxylase (ACCase) inhibitor mode-of-action is combined with the new herbicide, florpyrauxifen-benzyl from arylopicolinate group of synthetic auxin herbicide having disrupters of plant cell growth mode-of-action for broad spectrum weed control in direct-sown rice.

\section{Materials and Methods}

The experiment was conducted at Institute Research Farm of ICAR-National Rice Research Institute, Cuttack, Odisha $\left(20^{\circ} 27^{\prime} 10^{\prime \prime} \mathrm{N}, 85^{\circ} 56^{\prime} 9^{\prime \prime} \mathrm{E}\right.$; $24 \mathrm{~m}$ above mean sea level) in Kharif season of 2016 where adequate irrigation and drainage facilities are available. The experiment soil was sandy clay loam with $\mathrm{pH} 7.8$ with low available $\mathrm{N}(215.4 \mathrm{~kg} / \mathrm{ha})$, medium available $\mathrm{P}$ (48 kg/ha), high available $\mathrm{P}(322.8 \mathrm{~kg} / \mathrm{ha})$ and medium organic carbon $(0.52 \%)$. The experiment was laid out in Randomized Complete Block Design with nine treatments viz. four herbicide mixtures (florpyrauxifenbenzyl+cyhalofop-butyl 12\% EC (w/v) at $120(20+100) \mathrm{g} / \mathrm{ha}$, florpyrauxifen-benzyl+cyhalofop-butyl $12 \% \mathrm{EC}(\mathrm{w} / \mathrm{v})$ at 150 $(25+125) \mathrm{g} / \mathrm{ha}$, florpyrauxifen-benzyl+cyhalofop-butyl $12 \%$ EC (w/v) at $180(30+150) \mathrm{g} / \mathrm{ha}$, florpyrauxifenbenzyl+cyhalofop-butyl 12\% EC (w/v) at $360(60+300) \mathrm{g} / \mathrm{ha})$, three alone herbicides (florpyrauxifen-benzyl 2.5\% EC (w/v) at $25 \mathrm{~g} / \mathrm{ha}$, florpyrauxifen-benzyl $2.5 \% \mathrm{EC} \mathrm{(w/v)} \mathrm{at} 30 \mathrm{~g} / \mathrm{ha}$, bispyribac-sodium $10 \% \mathrm{SC}$ at $30 \mathrm{~g} / \mathrm{ha}$ ), one weed free and weedy check, replicated thrice. The gross and net plot size were $6.0 \mathrm{~m} \times 5.0 \mathrm{~m}$ and $5.0 \mathrm{~m}$ x $4.0 \mathrm{~m}$, respectively. The test variety 'Naveen' (115 days duration, Indica type) was sown manually at $20 \mathrm{~cm}$ rows apart with a seed rate of $80 \mathrm{~kg} / \mathrm{ha}$ on $13^{\text {th }}$ June and harvested on $6^{\text {th }}$ October, 2016.

Soil samples were collected diagonally from each plot before treatment of herbicides and at 4, 10, 20 and 30 days after treatment of herbicides for laboratory analysis of microbial biomass carbon (MBC) and soil enzymatic activities (Dehydrogenase activity, FDA hydrolase activity, Urease activity). The following methods were followed for analysis.

\section{Microbial Biomass Carbon}

Soil microbial biomass carbon (MBC) was measured by modified chloroform fumigation extraction method ${ }^{[24]}$. It was assayed by treating $10 \mathrm{~g}$ of fresh soil sample with $2 \mathrm{~mL}$ ethanol free chloroform in the soil sample and incubated for $24 \mathrm{hrs}$. In another set, soil was kept in similar condition except for chloroform treatment. After incubation, the lids of the container were opened to remove the chloroform vapors. $40 \mathrm{~mL}$ of $0.5 \mathrm{M} \mathrm{K}_{2} \mathrm{SO}_{4}$ was added to it. The content was shaken for at least $1 \mathrm{hr}$. The suspension was filtered and the filtrate was measured at $280 \mathrm{~nm}$ in UV-Visible spectrophotometer (Specord 200, Analytik Jena, Germany).

\section{FDA hydrolase activity}

FDA hydrolase activity was measured by the potassium phosphate buffer method followed by addition of chloroform/methanol $(2: 1 \mathrm{v} / \mathrm{v})$ as described by ${ }^{[1]}$. Soil samples $(2 \mathrm{~g})$ were treated with $15 \mathrm{ml}$ of $60 \mathrm{mM}$ potassium phosphate buffer (pH 7.6) and $0.2 \mathrm{ml}$ of $1,000 \mu \mathrm{g}$ FDA. After shaking for $20 \mathrm{~min}$ at $30^{\circ} \mathrm{C}, 15 \mathrm{ml}$ of chloroform/methanol $(2: 1 \mathrm{v} / \mathrm{v})$ was added and was centrifuged at 2,000 rpm for 3 min. FDA hydrolase activity was assayed at $490 \mathrm{~nm}$ and expressed as $\mu \mathrm{g}$ fluorescein per gram of dry soil per hour.

\section{Dehydrogenase activity}

Dehydrogenase activity (DHA) was determined by reduction of triphenyl tetrazolium chloride (TTC) ${ }^{[4]}$. Each soil sample $(3 \mathrm{~g})$ was treated with $0.1 \mathrm{~g} \mathrm{CaCO} 3$ and $1 \mathrm{~mL}$ aqueous $0.18 \mathrm{M}$ TTC and incubated for $24 \mathrm{~h}$ at $37^{\circ} \mathrm{C}$. The triphenyl formazan (TPF) was extracted from the reaction mixture ( $\mathrm{pH} 5.3-5.6)$ with methanol and assayed at $485 \mathrm{~nm}$. Dehydrogenase activity was expressed as milligrams of TPF formed per gram of dry soil per hour.

\section{Urease activity}

Twenty grams of soil samples from each treatment were mixed with urea $(20 \mathrm{~mL})$ to provide a final concentration of $2,000 \mu \mathrm{g} / \mathrm{g}$ soil, and the suspensions were incubated for $5 \mathrm{~h}$. The amount of residual urea present in the soil suspension upon incubation was determined by non-buffer method ${ }^{[25]}$. Urease activity was expressed as micrograms of urea hydrolyzed per gram of dry soil per hour.

\section{Statistical analysis}

The data were subjected to the Analysis of Variance using the Statistical Analysis System (SAS) and significant differences among the treatment means tested Fisher's protected Least Significant Difference (LSD) test at $\mathrm{p} \leq 0.05$.

\section{Results and Discussion \\ Microbial Biomass Carbon}

Among different microbial parameters, soil microbial biomass carbon (MBC) is considered to be responsible for regulating nutrient cycling ${ }^{[19]}$ and is closely linked to the primary productivity of an ecosystem ${ }^{[12]}$ and soil health ${ }^{[22]}$. The MBC data presented in Table 1 depicted that the biological property of soil was significantly affected by different weed management treatments. Among all treatments, the weed free and the weedy check did not show significant variation having higher MBC content in all stages of observations as they had not been applied with herbicides. There was a significant reduction in MBC content at 4 days after treatment (DAT) of the herbicides except bispyribac-sodium at $30 \mathrm{~g} / \mathrm{ha}$ $\left(84.40 \mu \mathrm{g} \mathrm{g}^{-1}\right)$ where the MBC content is higher than before treatment. 
Table 1: Effect of different weed management treatments on soil microbial biomass carbon (MBC)

\begin{tabular}{|c|c|c|c|c|c|c|}
\hline \multirow{2}{*}{ Treatments } & \multirow{2}{*}{ Dose $(\mathbf{g} / \mathbf{h a})$} & \multicolumn{5}{|c|}{ MBC $(\boldsymbol{\mu g} / \mathbf{g})$} \\
\cline { 3 - 7 } & & $\mathbf{B T}$ & 4 DAT & $\mathbf{1 0}$ DAT & 20 DAT & 30 DAT \\
\hline Florpyrauxifen-benzyl + cyhalofop-butyl & 120 & 68.58 & 47.61 & 51.62 & 63.96 & 59.26 \\
\hline Florpyrauxifen-benzyl + cyhalofop-butyl & 150 & 68.58 & 40.69 & 43.98 & 62.10 & 58.72 \\
\hline Florpyrauxifen-benzyl + cyhalofop-butyl & 180 & 68.58 & 24.77 & 32.73 & 53.26 & 57.36 \\
\hline Florpyrauxifen-benzyl + cyhalofop-butyl & 360 & 68.58 & 21.16 & 24.66 & 52.24 & 60.28 \\
\hline Florpyrauxifen-benzyl & 25 & 68.58 & 46.26 & 49.20 & 66.20 & 61.39 \\
\hline Florpyrauxifen-benzyl & 30 & 68.58 & 42.75 & 46.52 & 64.97 & 55.67 \\
\hline Bispyribac-sodium & 30 & 68.58 & 84.40 & 89.55 & 61.68 & 49.97 \\
\hline Weed Free & - & 68.58 & 86.72 & 102.11 & 51.10 & 70.72 \\
\hline Weedy (Control) & - & 68.58 & 82.27 & 92.32 & 40.78 & 65.81 \\
\hline SEm \pm & & - & 2.34 & 2.33 & 2.44 & 2.50 \\
\hline CD (P=0.05) & & - & 7.02 & 7.02 & 7.34 & 7.51 \\
\hline *BT: Before treatment & & & & & &
\end{tabular}

*BT: Before treatment

**DAT: Days after treatment

After 4 DAT, among the herbicide treatments, under florpyrauxifen-benzyl + cyhalofop-butyl at $120 \mathrm{~g} / \mathrm{ha}(47.61$ $\mu \mathrm{g} / \mathrm{g}$ ) highest MBC was observed which was at par with florpyrauxifen-benzyl at $25 \mathrm{~g} / \mathrm{ha}(47.61 \mu \mathrm{g} / \mathrm{g})$, florpyrauxifenbenzyl at $30 \mathrm{~g} / \mathrm{ha}(42.75 \mu \mathrm{g} / \mathrm{g})$ and florpyrauxifen-benzyl + cyhalofop-butyl at $150 \mathrm{~g} / \mathrm{ha}(40.69 \mu \mathrm{g} / \mathrm{g})$. The lowest MBC was observed under florpyrauxifen-benzyl + cyhalofop-butyl at $360 \mathrm{~g} / \mathrm{ha}(21.16 \mu \mathrm{g} / \mathrm{g})$ that was at par with florpyrauxifenbenzyl + cyhalofop-butyl at $180 \mathrm{~g} / \mathrm{ha}(24.77 \mu \mathrm{g} / \mathrm{g})$. Similar trend was also observed at 10 and 20 DAT whereas the MBC contents of all treatments decreased at 30 DAT.

It can be observed that herbicide mixture florpyrauxifenbenzyl + cyhalofop-butyl reduced the MBC content severely whereas there was a less reduction where florpyrauxifenbenzyl alone had been applied and there was least effect of bispyribac-sodium on soil MBC content. Short-term effects in response to the use of herbicides are related to disturbances of chemical and biological balance in soil, and are known to selectively suppress the activity of soil microorganisms. The decrease in MBC might be due to the adsorption of small amount of herbicides on organic matter that affected the soil microbial biomass, leading to lysis of microbial cells ${ }^{[14 \& 8]}$.

\section{FDA hydrolase activity}

FDA was considered as a tool for measuring the early detrimental effect of xenobiotics on soil microbial biomass. FDA is a sensitive and nonspecific test and able to depict the hydrolytic activity of soil microbes ${ }^{[13]}$. FDA hydrolase is considered as an accurate expression of total microbial activity. Data regarding FDA hydrolase activity as influenced by different treatments are presented in Table 2 .

Table 2: Effect of different weed management treatments on Fluoroscein Diacetate Hydrolase activity (FDA)

\begin{tabular}{|c|c|c|c|c|c|c|}
\hline \multirow{2}{*}{ Treatments } & \multirow{2}{*}{ Dose $(\mathbf{g} / \mathbf{h a})$} & \multicolumn{5}{|c|}{ FDA $(\boldsymbol{\mu}$ g fluroscein/g of dry soil/h) } \\
\cline { 3 - 8 } & & BT & 4 DAT & 10 DAT & 20 DAT & 30 DAT \\
\hline Florpyrauxifen-benzyl + cyhalofop-butyl & 120 & 3.319 & 4.195 & 2.050 & 2.456 & 3.402 \\
\hline Florpyrauxifen-benzyl + cyhalofop-butyl & 150 & 3.319 & 3.494 & 1.875 & 2.749 & 3.597 \\
\hline Florpyrauxifen-benzyl + cyhalofop-butyl & 180 & 3.319 & 3.585 & 1.872 & 2.389 & 3.407 \\
\hline Florpyrauxifen-benzyl + cyhalofop-butyl & 360 & 3.319 & 3.919 & 2.310 & 2.476 & 3.426 \\
\hline Florpyrauxifen-benzyl & 25 & 3.319 & 3.937 & 1.980 & 2.339 & 3.232 \\
\hline Florpyrauxifen-benzyl & 30 & 3.319 & 4.997 & 2.084 & 2.628 & 3.563 \\
\hline Bispyribac-sodium & 30 & 3.319 & 4.396 & 1.663 & 3.057 & 3.867 \\
\hline Weed Free & - & 3.319 & 4.741 & 1.801 & 2.414 & 3.425 \\
\hline Weedy (Control) & - & 3.319 & 5.933 & 1.557 & 2.761 & 3.566 \\
\hline SEm \pm & & - & 0.306 & 0.134 & 0.353 & 0.243 \\
\hline CD (P=0.05) & & - & 0.918 & 0.402 & NS & NS \\
\hline *BT: Before treatment & & & & & \\
**DAT: Days after treatment \\
***NS = Non-significant
\end{tabular}

The data revealed that by application of herbicides, FDA hydrolase activity of soil was increased up to 4 days. At 4 DAT, the FDA hydrolase activity was highest under the untreated weedy check $(5.933 \mu \mathrm{g}$ fluroscein/g of dry soil/h) followed by florpyrauxifen-benzyl at $30 \mathrm{~g} / \mathrm{ha}(4.997 \mu \mathrm{g}$ fluroscein/g of dry soil/h) which was at par with the weed free (4.741 $\mu \mathrm{g}$ fluroscein/g of dry soil/h), bispyribac-sodium at 30 $\mathrm{g} / \mathrm{ha}(4.396 \mu \mathrm{g}$ fluroscein/g of dry soil/h) and florpyrauxifenbenzyl + cyhalofop-butyl at $120 \mathrm{~g} / \mathrm{ha}$ ( $\mu \mathrm{g}$ fluroscein/g of dry soil/h) and the lowest found in florpyrauxifen-benzyl + cyhalofop-butyl at $150 \mathrm{~g} / \mathrm{ha}(3.494 \mu \mathrm{g}$ fluroscein/g of dry soil/h) which was at par with florpyrauxifen-benzyl + cyhalofop-butyl at $180 \mathrm{~g} / \mathrm{ha}(9.585 \mu \mathrm{g}$ fluroscein/g of dry soil/h), florpyrauxifen-benzyl + cyhalofop-butyl at $360 \mathrm{~g} / \mathrm{ha}$
(3.919 $\mu \mathrm{g}$ fluroscein/g of dry soil/h) and florpyrauxifenbenzyl at $25 \mathrm{~g} / \mathrm{ha}(3.937 \mu \mathrm{g}$ fluroscein/g of dry soil/h). The FDA hydrolase activities of all treatments decreased up to 10 DAT and increased between 10 and 30 DAT. At both 20 and 30 DAS the treatment effects on FDA hydrolase was nonsignificant. This result indicated that the herbicides had no detrimental effect on FDA hydrolase of soil.

\section{Dehydrogenase activity}

Soil dehydrogenase activity is considered as a valuable parameter for assessing the impact of herbicide treatments on the soil microbial biomass ${ }^{[17]}$. Data regarding dehydrogenase activity (DHA) as influenced by different treatments are presented in Table 3. 
Table 3: Effect of different weed management treatments on Dehydrogenase activity (DHA)

\begin{tabular}{|c|c|c|c|c|c|c|}
\hline \multirow{2}{*}{ Treatments } & \multirow{2}{*}{ Dose (g/ha) } & \multicolumn{5}{|c|}{ DHA (mg TPF/g of dry soil/h) } \\
\hline & & BT & 4 DAT & 10 DAT & 20 DAT & 30 DAT \\
\hline Florpyrauxifen-benzyl + cyhalofop-butyl & 120 & 8.561 & 5.765 & 19.463 & 32.529 & 28.202 \\
\hline Florpyrauxifen-benzyl + cyhalofop-butyl & 150 & 8.561 & 5.093 & 22.579 & 36.342 & 30.432 \\
\hline Florpyrauxifen-benzyl + cyhalofop-butyl & 180 & 8.561 & 4.961 & 17.028 & 27.495 & 24.489 \\
\hline Florpyrauxifen-benzyl + cyhalofop-butyl & 360 & 8.561 & 3.370 & 14.035 & 25.552 & 20.426 \\
\hline Florpyrauxifen-benzyl & 25 & 8.561 & 9.505 & 15.297 & 29.271 & 24.849 \\
\hline Florpyrauxifen-benzyl & 30 & 8.561 & 9.313 & 14.201 & 28.962 & 22.499 \\
\hline Bispyribac-sodium & 30 & 8.561 & 8.777 & 16.799 & 21.024 & 19.431 \\
\hline Weed Free & - & 8.561 & 8.421 & 11.222 & 18.061 & 16.341 \\
\hline Weedy (Control) & - & 8.561 & 8.392 & 12.024 & 19.251 & 17.438 \\
\hline SEm \pm & & - & 0.477 & 0.955 & 2.015 & 1.803 \\
\hline $\mathrm{CD}(\mathrm{P}=0.05)$ & & - & 1.431 & 2.863 & 6.042 & 5.406 \\
\hline
\end{tabular}

*BT: Before treatment

**DAT: Days after treatment

The data revealed that on 4 DAT of herbicides, the DHA content of weed free $(8.421 \mathrm{mg} \mathrm{TPF} / \mathrm{g}$ of dry soil/h), weedy check ( $8.392 \mathrm{mg} \mathrm{TPF} / \mathrm{g}$ of dry soil/h) and bispyribac-sodium at $30 \mathrm{~g} / \mathrm{ha}(8.777 \mathrm{mg} \mathrm{TPF} / \mathrm{g}$ of dry soil/h) remained almost unaffected whereas, there was a slight increase in florpyrauxifen-benzyl at $25 \mathrm{~g} / \mathrm{ha}(9.505 \mathrm{mg} \mathrm{TPF} / \mathrm{g}$ of dry soil/h) and florpyrauxifen-benzyl at $30 \mathrm{~g} / \mathrm{ha}(9.313 \mathrm{mg} \mathrm{TPF} / \mathrm{g}$ of dry soil/h) and sharp decrease in herbicide mixture treatments. The highest decrease occurred in florpyrauxifenbenzyl + cyhalofop-butyl at $360 \mathrm{~g} / \mathrm{ha}$ (3.370 mg TPF/g of dry soil/h) followed by florpyrauxifen-benzyl + cyhalofop-butyl at $180 \mathrm{~g} / \mathrm{ha}(4.961 \mathrm{mg} \mathrm{TPF} / \mathrm{g}$ of dry soil/h), florpyrauxifenbenzyl + cyhalofop-butyl at $150 \mathrm{~g} / \mathrm{ha}(5.093 \mathrm{mg} \mathrm{TPF} / \mathrm{g}$ of dry soil/h) and florpyrauxifen-benzyl + cyhalofop-butyl at 120 $\mathrm{g} / \mathrm{ha}(5.765 \mathrm{mg} \mathrm{TPF} / \mathrm{g}$ of dry soil/h). The finding is in agreement with the finding of Sebiomo et al. ${ }^{[16]}$ who observed that the application of herbicides to the soils led to a significant drop in DHA with respect to untreated soil samples.

However, after 4 DAT of herbicides, there was a notable increase in DHA content in the herbicide treated soil than the untreated weed free and the weedy check up to 20 DAT, which might be due to the greater availability of carbon source for the growth and activity of micro-organisms. This result is in close agreement with the findings of Rao et al. ${ }^{[15]}$.
The lower dehydrogenase activity in the untreated plots might be attributed to the lower availability of substrate for growth of soil microbes. At 30 DAT, there was a higher dehydrogenase activity observed in the soil as compared to the weed free and weedy check.

\section{Urease activity}

Urease catalyzes the hydrolysis of urea to ammonium and carbon dioxide. Ammonium formed represents a bioavailable form of nitrogen for plant uptake; has a primary role in the cycling of nitrogen. Data regarding urease activity as influenced by different treatments are presented in Table 4 .

A reduction in the urease activity was observed at 4 DAT which might be attributed to the changes in soil properties like $\mathrm{pH}$ and also due to the temporary inhibition caused by the metabolites produced as a result of degradation of herbicides by the micro-organisms as reported by Sheeja et al. ${ }^{[17]}$. As time advanced there was an increase in the urease activity might be due to the fact that the temporary inhibition of enzyme activity was overcome by the increased microflora with the increase in microbial population. More the microbial biomass, more the exudation resulted in higher enzymatic activity ${ }^{[10]}$. With the advancement of time, all the herbicide treatments except the highest dose i.e. florpyrauxifen-benzyl + cyhalofop-butyl at $360 \mathrm{~g} / \mathrm{ha}$.

Table 4: Effect of different weed management treatments on urease activity

\begin{tabular}{|c|c|c|c|c|c|c|c|}
\hline \multirow{2}{*}{ Treatments } & \multirow{2}{*}{$\begin{array}{c}\text { Dose } \\
\text { (g/ha) }\end{array}$} & \multicolumn{5}{|c|}{ Urease ( $\mu \mathrm{g}$ of urea hydrolysed/g of dry soil/h) } & \multirow{2}{*}{$\begin{array}{c}\text { Grain Yield } \\
\text { (t/ha) }\end{array}$} \\
\hline & & BT & 4 DAT & 10 DAT & 20 DAT & 30 DAT & \\
\hline Florpyrauxifen-benzyl + cyhalofop-butyl & 120 & 349.60 & 325.90 & 326.98 & 365.62 & 351.36 & 4.68 \\
\hline Florpyrauxifen-benzyl + cyhalofop-butyl & 150 & 349.60 & 268.50 & 253.33 & 350.75 & 368.42 & 4.91 \\
\hline Florpyrauxifen-benzyl + cyhalofop-butyl & 180 & 349.60 & 341.97 & 309.72 & 354.28 & 365.33 & 4.17 \\
\hline Florpyrauxifen-benzyl + cyhalofop-butyl & 360 & 349.60 & 334.08 & 263.72 & 325.85 & 337.14 & 3.72 \\
\hline Florpyrauxifen-benzyl & 25 & 349.60 & 334.94 & 291.88 & 355.06 & 367.85 & 4.46 \\
\hline Florpyrauxifen-benzyl & 30 & 349.60 & 336.75 & 285.68 & 364.77 & 358.27 & 4.74 \\
\hline Bispyribac-sodium & 30 & 349.60 & 318.57 & 347.00 & 359.62 & 345.63 & 4.36 \\
\hline Weed Free & - & 349.60 & 281.03 & 264.78 & 359.10 & 366.95 & 5.27 \\
\hline Weedy (Control) & - & 349.60 & 333.37 & 329.82 & 327.12 & 361.78 & 3.14 \\
\hline SEm \pm & & - & 6.19 & 9.98 & 4.77 & 4.74 & 0.17 \\
\hline $\mathrm{CD}(\mathrm{P}=0.05)$ & & - & 18.56 & 29.92 & 14.32 & 14.21 & 0.52 \\
\hline
\end{tabular}

*BT: Before treatment

**DAT: Days after treatment

\section{Grain yield}

All the herbicide treatments significantly influenced the grain yield (Table 4). The highest grain yield was obtained under weed free (5.27 t/ha) which was at par with florpyrauxifenbenzyl + cyhalofop-butyl at $150 \mathrm{~g} / \mathrm{ha}$ (4.91 t/ha). The treatments florpyrauxifen-benzyl at $30 \mathrm{~g} / \mathrm{ha}$ (4.74 t/ha), florpyrauxifen-benzyl + cyhalofop-butyl at $120 \mathrm{~g} / \mathrm{ha}(4.68$ $\mathrm{t} / \mathrm{ha})$, florpyrauxifen-benzyl at $25 \mathrm{~g} / \mathrm{ha}(4.46 \mathrm{t} / \mathrm{ha})$ and bispyribac-sodium at $30 \mathrm{~g} / \mathrm{ha}(4.36 \mathrm{t} / \mathrm{ha})$ recorded at par grain yield. The lowest grain yield was obtained under weedy check $\left(3.14 \mathrm{t} \mathrm{ha}^{-1}\right)$ followed by florpyrauxifen-benzyl + cyhalofopbutyl at $360 \mathrm{~g} / \mathrm{ha}(3.72 \mathrm{t} / \mathrm{ha})$ and florpyrauxifen-benzyl + 
cyhalofop-butyl at $180 \mathrm{~g} / \mathrm{ha}$ (4.17 t/ha). At par yield in both 150 and $180 \mathrm{~g} / \mathrm{ha}$ doses of florpyrauxifen-benzyl + cyhalofop butyl herbicide mixture was reported in aerobic rice ${ }^{[23]}$.

\section{Conclusions}

All the herbicide treatments significantly affected the soil environment of wet-DSR. At 4 days after herbicide application, approximately all the soil environmental parameters were decreased except FDA hydrolase activity. There was a drastic reduction in soil microbial-biomass carbon in all the herbicide treatments except bispyribacsodium where an increased value was observed at 4 days after herbicide treatment. After 4 days of herbicide treatment, dehydrogenase activity increased gradually. Similarly the urease activity showed at par result in all the plots except the highest dose of herbicide. All the four parameters i.e. microbial-biomass carbon, FDA hydrolase activity, dehydrogenase activity and urease activity showed normal behaviour after 10 days of herbicide treatments. The grain yield was highest in florpyrauxifen-benzyl + cyhalofop-butyl at $150 \mathrm{~g} / \mathrm{ha}$ being at par with the weed free showing no detrimental effect on soil environment, hence may be recommended for sustainability in wet direct-sown rice.

\section{References}

1. Adam G, Duncan H. Development of sensitive and rapid method for the measurement of total microbial activity using fluoroscein diacetate (FDA) in a range of soils. Soil Biol. Biochem 2001;33: 943-951.

2. Asad MA, Michel L, Hao S, Yujian J, Zhengwei F, Haifeng Q et al. Interaction of chiral herbicides with soil microorganisms, algae and vascular plants. Sci. Total Environ 2017;580:1287-1299.

3. Balasubramanian V, Hill JE. Direct seeding of rice in Asia: emerging issues and strategic research needs for the 21st century. In: Pandey et al, editors. Direct seeding: research strategies and opportunities. Proceedings of the International Workshop on Direct Seeding in Asian Rice Systems. Los Baños (Philippines): International Rice Research Institute 2002, 5-39.

4. Casida LE, Klein DA, Santoro T. Soil dehydrogenase activity. Soil Sci 1964;98:371-376.

5. Chatterjee D, Kumar R, Kuotsu R, Deka BC. Validation of traditional weed control method through common salt application in hill region of Nagaland. Current Sci 2016;110(8):1159-1167.

6. Das AC, Ritwika D, Sourav B. Non-symbiotic N2fixation and phosphate-solubility in Gangetic alluvial soil as influenced by preemergence herbicide residues. Chemosphere 2015;135:202-207.

7. Hatzios KK, Penner D. Interactions of herbicides with other agrochemicals in higher plants. Rev. Weed Sci 1985; 1:1-63.

8. Jayamadhuri R, Rangaswamy V. Influence of orghorous and carbamate insecticides on enzymatic activities of amylase, cellulase and invertase in two groundnut soil, Nature, Environ. Pollution Tech. 2005;4:385-393.

9. Latha PC, Gopal G. Influence of herbicides on cellulolytic, proteolytic and phosphate solubalizing bacteria. Int. J Plant Prot 2010;3(1):83-88.

10. Lu-Sheng Z, Min L, Cheng-li C, Chang-Yong. Variation of soil microbial biomass and enzyme activities at different growth stages of rice (Oryza sativa). Rice Sci $2005 ; 12: 283-88$.
11. Mahajan G, Chauhan BS, Timsina J, Singh PP, Singh K. Crop performance and water- and nitrogen-use efficiencies in dry-seeded rice in response to irrigation and fertilizer amounts in northwest India. Field Crops Res 2012;134:59-70.

12. Marcel GA, Heijden VD, Bardgett RD, Vanstraalen NM. The unseen majority: Soil microbes as drivers of plant diversity and productivity in terrestrial ecosystems. Ecol. Lett 2008;11:296-310.

13. Nayak D, Jagadeesh Babu Y, Adhya TK. Long-term application of compost influences microbial biomass and enzyme activities in a tropical Aeric Endoaquept planted to rice under flooded condition. Soil Biol. Biochem 2007;39:1897-1906.

14. Perucci P, Scarponi L. Effects of the herbicide imazethapyr on soil microbial biomass and various soil enzyme activities, Biol. Fertility and Soils 1994;17:237240.

15. Rao PC, Lakshmi CSR, Sireesha A, Madhavi M, Swapna G. Effect of oxadiargyl on soil enzyme activity. J Crop Weed 2012;8:52-56.

16. Sebiomo A, Ogundero VW, Bankole SA. Effect of four herbicides on microbial population, soil organic matter and dehydrogenase activity. Afr. J Biotechnol 2011;10:770-778.

17. Sheeja KR, Elizabeth KS, Girija Devi L, Meenakumari KS, Vijayaraghavakumar, Aparna B. Impact of new herbicide molecule bispyribac sodium+metamifop on soil health under direct seeded rice lowland condition. Crop Res 2015;50(1- 3):1-8.

18. Sheeja KR, Elizabeth KS. Weed management in direct seeded rice: A review. Agric. Rev 2017;38(1):41-50.

19. Singh M, Bhullar MS, Chauhan BS. The critical period for weed control in dry-seeded rice. Crop Prot 2014;66:80-85.

20. Singh JS, Raghubanshi AS, Singh RS, Srivastava SC. Microbial biomass acts as a source of a plant nutrients in dry tropical forest and savanna. Nature 1989;338:499500.

21. Singh SK, Abraham T, Singh AK, Kumar S, Kumar R. Response of crop establishment methods and split application of nitrogen on productivity of rice. Environ. Ecol 2017;35(2A):859-862.

22. Sparling GP. Soil microbial biomass, activity and nutrient cycling as indicator of soil health. In Pankhurst C, Doube BM, Gupta VVSR. (Eds.). Biological indicators of soil health Wallingford: CAB International 1997, 97-119.

23. Sreedevi B, Singh A, Thakur C, Kumar MP, Mehra V, Mahenderkumar R, Srivastava GK. Weed Control by Single Post-emergenceCombination Herbicide Florpyrauxifen-Benzyl plus Cyhalofop Butyl in Aerobic Rice. Curr. j. appl. sci. technol. 2020; 39(3): 109-122.

24. Vance ED, Brookes PC, Jenkinson DS. An Extraction Method for Measuring Soil Microbial Biomass C. Soil Biol. Biochem 1987;19(6):703-707.

25. Zantua MI, Bremner JM. Stability of Urease in soils. Soil Biol. Biochem 1977;9:135-140. 